\title{
LOS DERECHOS HUMANOS EN LA \\ OPINIÓN CONSULTIVA SOBRE ARMAS \\ NUCLEARES DE 1996
}

\section{THE HUMAN RIGHTS AT THE ADVISORY OPINION ON NUCLEAR WEAPONS OF 1996}

\section{Nieves Irene Caballero Pérez}

Universidad Pablo de Olavide, Sevilla, España

nievescab90@gmail.com

Palabras clave: Tribunal Internacional de Justicia, Derechos Humanos, Derecho Internacional Humanitario, principio Lotus, principio non liquet.

Keywords: The International Court of Justice, Human Rights, International Humanitarian Law, Lotus principle, non liquet principle.

Resumen: En la Opinión Consultiva de 8 de julio de 1996, el Tribunal Internacional de Justicia debía dictaminar sobre si la amenaza o uso de armas nucleares era legal conforme al Derecho Internacional, su resolución supuso un precedente esencial sobre la prevención de los Derechos Humanos como principio del Derecho Internacional. La decisión del Tribunal recordó la importancia de velar por el cumplimiento de los Derechos Humanos a través de la aplicación de sus normas internas. En la presente comunicación se analizará dicha opinión consultiva, sus antecedentes jurisprudenciales y su posterior impacto en las normas del Derecho Internacional.

Abstract: In the Advisory Opinion of 8 July 1996, the International Court of Justice was required to decide on whether it was legal the threath or use of nuclear weapons under International Law, its decision supposed an essential precedent concerning the prevention of Human Rights as a principle of International Law. The decision of the Court remembered the importance of ensuring the compliance of the Human Rights by means of the excercise of their internal rules. In this paper will analyse regarding this advisory opinion, its jurisprudential background and its subsequent impact on the rules of International Law.

\section{l.- Introducción}

La Declaración Universal de los Derechos Humanos de 10 de diciembre de 1948, junto con la propia Carta de Naciones Unidas de fecha 26 de junio de 1945, supone la centralidad del sistema normativo actual del Derecho Internacional. 
La jurisprudencia del Tribunal Internacional de Justicia no suele argumentar sus resoluciones en los derechos reconocidos por la Declaración Universal y los tratados que lo desarrollan, pues su finalidad principal es resolver los conflictos que se suscitan entre los Estados, y son éstos los obligados a garantizar, preservar y promover, a través de su Derecho Interno, su vigencia y reconocimiento. Con independencia de los numerosos precedentes relativos al Derecho Humanitario como núcleo esencial de prevención de la dignidad humana, existen algunos antecedentes en los que se ponen de manifiesto su importancia por parte del Tribunal. Prueba de ello es lo que expuso el juez Kotaro Tanaka, en su voto particular en el caso de Sudoeste de África de 18 de julio de 1966, cuando afirmó: "The principle of the protection of human rights is derived from the concept of man as a person and his relationship with society which cannot be separated from universal human nature. The existence of human rights does not depend on the will of a State; neither internally on its law or any other legislative measure, nor internationally on treaty or custom, in which the express or tacit will of a State constitutes the essential element" (International Court of Justice, 1966: 295).

El Tribunal Internacional de Justicia, mediante la Opinión Consultiva sobre la amenaza o uso legal de armas nucleares de 8 de julio de 1996, sentó uno de los aspectos más relevantes dentro del Derecho Internacional determinando la presencia de la Declaración Universal de los Derechos Humanos en su jurisprudencia. Igualmente, esta opinión consultiva conllevó la superación del denominado "principio Lotus" ${ }^{1}$ en un intento por parte de

1. La Corte Permanente de Justicia Internacional, el 7 de septiembre de 1927, dictó una sentencia los magistrados del Tribunal de resolver la consulta planteada.

La presente comunicación tiene como fin la reinterpretación de la Opinión Consultiva de 8 de julio de 1996, desde el punto de vista de los principios aplicables en ausencia de norma convencional o consuetudinaria de Derecho Internacional, así como sus antecedentes y su impacto posterior en la doctrina y jurisprudencia del Tribunal.

\section{Metodología}

El estudio sobre la evolución de la historia del Derecho, así como el estudio de la doctrina y jurisprudencia del Tribunal Internacional de Justicia son esenciales dentro del marco metodológico en la presente comunicación.

El objetivo principal de esta comunicación se fundamenta en la interpretación y reinterpretación, sobre los fundamentos de derecho de la Opinión Consultiva sobre el uso de armas nucleares de 8 de julio de 1996, así como sus conceptos y principios jurídicos que, previstos indirectamente, refuerzan la visión de los jueces del Tribunal sobre el citado caso; conllevando la inclusión del constructivismo jurídico dentro del marco metodológico, pues a través de la reinterpretación tanto de las normas como de la doctrina existente al momento de dictarse la opinión consultiva, se ofrece otra perspectiva sobre la misma.

al resolver un conflicto sobre el ejercicio de la jurisdicción entre Turquía y Francia ante la ausencia de norma convencional o consuetudinaria del Derecho Internacional que fuera aplicable, y con la finalidad de establecer una cláusula de cierre para resolver la cuestión, estableció el principio que todo lo que no estuviere prohibido por el Derecho Internacional, debía entenderse por "permitido". Al estimar que las normas internacionales suponían un ordenamiento jurídico completo. 
Por último, merece especial atención el enfoque mixto entre teórico y objetivo, por cuanto la finalidad de esta comunicación es la práctica de las teorías jurídicas existentes en relación con el caso objeto de estudio, determinando la metodología explicativa como el segundo marco esencial dentro del presente estudio, por cuanto la finalidad del mismo es una reinterpretación de la opinión consultiva sobre el ejercicio de los Derechos Humanos dentro del Derecho Internacional y del Derecho Interno de los Estados.

\section{Resultados}

La decisión de la opinión consultiva sobre el uso o amenaza de armas nucleares conllevó que el Tribunal Internacional de Justicia constituyera un precedente seguido por resoluciones posteriores, remitiéndose de forma directa a la Declaración Universal de los Derechos Humanos como principio de Derecho Internacional, recordando la obligación de los Estados de velar por el respeto a las personas por su condición humana.

El establecimiento del principio de la dignidad humana, aplicable no sólo en el Derecho Internacional Humanitario, considero que conlleva una reinterpretación del principio Lotus, utilizado tradicionalmente en la jurisprudencia del Tribunal, así como por la Corte Permanente de Justicia Internacional para resolver los casos en ausencia de Derecho Internacional directamente aplicable, pues la solución dada en este caso por el Tribunal conlleva a cuestionar los objetivos normativos del mismo².

2. Los profesores Ann Hertogen, en su artículo "Letting Lotus Bloom"; Teresa O'Neill, en su tesis "Rethinking the Lotus Principle: New perspectives on the Kosovo Advisory Opinion";
Ya esta postura fue puesta de manifiesto en el propio asunto Lotus por el profesor y juez de la Corte Permanente de Justicia Internacional Rafael Altamira y Crevea, que recoge en su voto particular no sólo la centralidad de la persona dentro del sistema normativo del Estado, sino que toda aplicación de sus normas internas debe ser conforme al respeto de los principios y valores de la comunidad internacional. Así:

"En dehors du domaine particulier à ce droit, mais toujours dans celui du droit général humain, je trouve d'autres motifs pour ne pas pouvoir accepter la consécration de la règle de la liberté absolue. Ces motifs sont puisés dans ce qui, pour moi, constitue la base de tout le régime juridique social: le respect des droits de la personnalité humaine. Ce respect doit primer tout. S'il fait défaut, tout le reste s'écroule et manque de raison juridique (...).

Dans toutes les époques de l'histoire, les hommes ont vu dans l'application de leurs propres lois, de leur procédure nationale, et dans la soumission de leurs affaires juridiques à des juges de leur propre langue et nationalité, une garantie de leurs droits aussi importante que l'est, à tout autre point de vue, l'appréciation spéciale des circonstances particulières qui environnent les faits en question et qui portent, bien des fois, à adoucir la pénalité prévue en principe. Ceux qui appartiennent à des nations où plus d'une langue est parlée et plus d'une législation est acceptée comme valable devant les tribunaux, connaissent bien la grande valeur qu'on attache parfois à l'individualité de la juridiction invoquée. A plusieurs reprises, cette question s'est trouvée placée parmi les revendications les plus pressantes

y Hugh Handeyside, en su artículo "The Lotus Principle in ICJ Jurisprudence: Was the Ship ever Afloat?"; ya pusieron de manifiesto la reinterpretación de dicho principio. 
des régions et des groupes divers de la population complexe des pays auxquels je fais allusion" (Permanent Court of International Justice, 1927: 104-105).

Esta doctrina, y la visión de los jueces del Tribunal Internacional de Justicia sobre la importancia de la protección de los Derechos Humanos dentro del Derecho Interno de los Estados, se ha observado posteriormente en su jurisprudencia, como los casos sobre la aplicación de la Convención para la prevención y sanción del delito de Genocidio de 11 de julio de 1996 (Bosnia-Herzegovina c. Yugoslavia), 26 de febrero de 2007 (Bosnia-Herzegovina c. Serbia y Montenegro), 18 de noviembre de 2008 (Croacia c. Serbia), y 3 de febrero 2015 (Croacia c. Serbia).

El caso sobre la aplicación de la Convención sobre la eliminación de toda forma de discriminación racial de 1 de abril de 2011 (Georgia c. Federación de Rusia) merece especial atención, pues su fundamento jurídico refleja la importancia de los instrumentos jurídicos sobre los Derechos Humanos en la administración y gestión territorial de los Estados, incluso en los supuestos de conflictos interestatales ${ }^{3}$.

Indirectamente, los fundamentos expuestos por los distintos jueces del Tribunal

3. En la actualidad, hay dos casos pendientes de resolución por parte del Tribunal Internacional de Justicia, en los que puede influir el principio de preservación de los Derechos Humanos, el primero de ellos sobre la supresión de financiación terrorista y sobre la aplicación de la Convención sobre la eliminación de toda forma de discriminación racial (Ucrania c. Federación de Rusia), mediante orden de 19 de abril de 2017, y el segundo de ellos sobre la aplicación de la Convención sobre la eliminación de toda forma de discriminación racial (Qatar c. Emiratos Árabes Unidos), prevista en las órdenes de 23 de julio de 2018 y de 14 de junio de 2019. en la Opinión Consultiva de 8 de julio de 1996 supuso una superación del principio Lotus, pues ante la ausencia de normas convencionales y consuetudinarias que resulten de aplicación, no impide que se tengan en consideración nuevas visiones jurídicas que determinen una limitación a la permisibilidad por el Derecho Internacional de la actuación de los Estados, cuando ésta supone un riesgo para la civilización y la humanidad.

El Tribunal Internacional de Justicia, en esta opinión consultiva, y sobre la base de la prevención de los Derechos Humanos, reconoce como principio de Derecho Internacional los valores de la humanidad, esencialmente en el Derecho Humanitario, pero no exclusivamente dentro del mismo, derivado todo ello de la centralidad del ser humano en todo sistema normativo.

\section{Discusión}

En un primer acercamiento, los Derechos Humanos son definidos desde dos puntos de vista esenciales dentro del Derecho: 1) desde la visión del Derecho Natural, los Derechos Humanos son definidos como aquellas normas, en virtud de las cuales las personas son consideradas como el centro del sistema normativo ${ }^{4}$, perspecti-

4. Esta visión, dentro del Derecho Internacional, se puso de manifiesto mediante el voto el particular del profesor Rafael Altamira y Crevea en el asunto Lotus de 1927, caso por el que la Corte Permanente de Justicia Internacional debía resolver si la actuación por parte del Estado turco, en relación con el procesamiento y enjuiciamiento del Teniente Demons por el abordaje entre el S.S. Lotus, bajo bandera francesa, y el buque mercante Borz-Kourt, bajo pabellón turco; en el que fallecieron 8 personas de nacionalidad turca era conforme a las normas convencionales y consuetudinarias internacionales. 
va que, de acuerdo con el profesor Carlos Santiago Nino, determina que la humanidad actúa como legislador en la creación y desarrollo "espiritual" de dichas normas (1989: 11-25); y 2) desde el punto de vista del Derecho Positivo, los Derechos Humanos se definen como aquel conjunto de normas que, a través de las mismas, garantizan la convivencia de una colectividad entre los miembros conforme a los principios y valores previstos en su ordenamiento jurídico.

Igualmente, y compartiendo la exposición del profesor Patrick Macklem en su obra The Sovereignty of Human Rights, podemos considerar la Declaración Universal de los Derechos Humanos desde una triple perspectiva: 1) desde un punto de vista moral, determina que las personas, por su condición, tienen una serie de derechos que son compartidos universalmente con los demás miembros de una colectividad a través de valores que aseguran la convivencia con los demás; 2) desde una visión política, en cuanto vincula su garantía a una serie de actuaciones y de mecanismos tantos internos como internacionales, y por último 3) desde una visión estrictamente jurídica, y con mayor relevancia dentro del Derecho Internacional, que entiende que los Derechos Humanos suponen el conjunto de normas "positivas" que garantizan la seguridad jurídica y el cumplimiento a través de la actuación de "buena fe" de los Estados en virtud de lo establecido principalmente en normas convencionales (2015: 1-28).

Jurídicamente, los Derechos Humanos suponen la existencia de un sistema normativo que concreta la dignidad, la libertad y la igualdad humana en cada momento histórico, que determina su reconocimiento positivo por los ordenamientos jurídicos tanto a nivel nacional como internacional (Pérez Luño, 2007: 46), fundado en la materialidad de la razón y consciencia de que "[t]odos los seres humanos nacen libres e iguales en dignidad y derechos y, dotados como están de razón y conciencia, deben comportarse fraternalmente los unos con los otros" (artículo 1 de la Declaración Universal de los Derechos Humanos), y específicamente desde el punto de vista del Derecho Internacional, las personas como centralidad fundamental dentro del sistema normativo, especialmente mediante normas convencionales como la Carta de las Naciones Unidas, el Tratado contra la Tortura de 1984 o la Convención para la Prevención y Sanción del Delito de Genocidio de $1948^{5}$. Considero, tras analizar esta postura y de acuerdo con la exposición de la jueza del Tribunal Internacional de Justicia Rosalyn Higgins, que el Derecho Internacional está formado por un sistema normativo, en el que existe un conjunto de normas que garantizan los valores y principios esenciales para la convivencia con los demás miembros de una colectivi-

5. De acuerdo con el Alto Comisionado de Derechos de las Naciones Unidas, existen en la actualidad nueve tratados internacionales, junto con los Protocolos existentes, en los que tenga por finalidad la protección y regulación de los Derechos Humanos. Amén de los tratados principales ya citados, debemos resaltar, la Convención Internacional sobre los Derechos Civiles y Políticos de 1966, la Convención Internacional sobre los Derechos Económicos, Sociales y Culturales del mismo año, la Convención sobre la Eliminación de todas forma de discriminación contra la mujer de 1979, la Convención de los Derechos del Niño de 1989, la Convención sobre los Derechos de las Personas Discapacitadas de 2006, y la Convención Internacional sobre la Protección de Derechos de todas las Personas contra las Desapariciones Forzadas del mismo año. 
dad, así como el deber del cumplimiento derivado de dichas normas ${ }^{6}$.

La construcción del "sistema normativo" de los Derechos Humanos no es un fenómeno reciente, el profesor Gentian Zyberi, en su tesis "The Humanitarian Face of the International Court of Justice. Its Contribution to Interpreting and Developing International Human Rights and Humanitarian Law Rules and Principles", observó la evolución fundamental en relación con el Derecho Internacional Humanitario, y puede encontrarse en sentencias y opiniones consultivas del Tribunal Internacional de Justicia ${ }^{7}$. Zyberi afirmó que "the Court has been able to progressively develop and interpret norms of the international law of human rights, hence contributing to an international legal order where human rights are given a prominent place" (2008: 252), reforzando

6. Igualmente, la magistrada del Tribunal Internacional Justicia Rosalyn Higgins, en su obra "Problems and Process: International Law and How we use it", afirmó lo siguiente: "International Law is not rules. It is a normative system. All organized groups and structures require a system of normative conduct-that is to say, conduct which is regarded by each actor, and by the group as a whole, as being obligatory, and for which violation carries a price. Normative systems make possible that degree of order if society is to maximize the common good (...)" (1994: 1).

7. Sobre la evolución de este fenómeno en la jurisprudencia del Tribunal Internacional de Justicia y su posterior impacto, véase Bedi, Shiv R.S. (2007). The development of Human Rights Law by the judges of the International Court of Justice. Studies in International Law, Volume 10, Oxford: Hart Publishing; y Rieter, Eva. (2019). "The International Court of Justice and its contribution to Human Rights Law", en Kadelbach, Stefan; Rensmann, Thilo y Rieter, Eva [eds.], Judging International Human Rights. Courts of General Jurisdiction as Human Courts. Switzerland: Springer International Publishing A.G. su necesidad en la idea de que los Derechos Humanos "[have] to be respected and promoted by all States for they have a civilizing and humanitarian character" (2008: 253). Existen críticas, con relación a la interpretación que la Corte viene realizando sobre la centralidad de los Derecho Humanos, así la jueza del Tribunal Rosalyn Higgins ya afirmó que "this vast explosion of human rights conventions could, it might have been thought, lead to a heavy human rights component in the Court's work. The reality, however, is different" (1998: 693).

En la jurisprudencia del Tribunal Internacional de Justicia pueden encontrarse algunos precedentes que recuerdan a los Estados el deber de actuar promoviendo y garantizando el ejercicio de los Derechos Humanos, y la buena fe en el cumplimiento de las normas convencionales o consuetudinarias ${ }^{8}$.

Así, la opinión consultiva sobre la interpretación de lo tratados de paz de Hungría, Bulgaria y Rumanía de 30 de marzo y 18 de julio de 1950 supuso una de las primeras declaraciones en la que los miembros del Tribunal resaltan la importancia de la Declaración Universal de los Derechos Humanos, y el carácter universal de éstos, y de las libertades fundamentales, y con fundamento con el artículo 55 de la Carta de las Naciones Unidas ${ }^{9}$, la protec-

8. En relación sobre las contribuciones del Tribunal Internacional de Justicia sobre los Derechos Humanos y el Derecho Internacional Humanitario, la profesora Dominika Švarc Pipan observó que "the role of the ICJ in the global framework for the enforcement of these two branches of international law in an important addtional pillar for the invocation of State responsibility in this field" (2018: 222).

9. El citado precepto determina la exigencia de promover "el respeto universal a los derechos 
ción de los derechos dentro del ejercicio soberano de los Estados, garantizando así el cumplimiento del principio de no intervención soberana.

En la Opinión Consultiva sobre las consecuencias jurídicas en los Estados africanos acerca de la continuación de la presencia de Sudáfrica en Namibia de fecha 21 de junio de 1971, el Tribunal reconoció la ilegalidad de la permanencia de las autoridades sudafricanas en el Estado de Namibia, así como la invalidez de las actuaciones realizadas en nombre de Sudáfrica dentro del Gobierno namibio; y afirmó, en relación con la obligación de los Estados de respetar los Derechos Humanos, lo siguiente: "En vertu de la Charte des Nations Unies. l'ancien mandataire s'était engagé à observer et à respecter, dans un territoire ayant un statut international, les droits de l'homme et les libertés fondamentales pour tous sans distinction de race. Le fait d'établir et d'imposer, au contraire, des distinctions, exclusions, restrictions et limitations qui sont uniquement fondées sur la race, la couleur, l'ascendance ou l'origine nationale ou ethnique et qui constituent un déni des droits fondamentaux de la personne humaine, est une violation flagrante des buts et principes de la Charte" (International Court of Justice, 1971: 45). En este caso, el Tribunal advierte que la existencia de normas internas, contrarias a los principios y normas de Derecho Internacional sobre el respeto y protección de los Derechos Humanos, constituiría una violación de los principios y valores del Derecho Internacional.

humanos y a las libertades fundamentales de todos, sin hacer distinción por motivos de raza, sexo, idioma o religión, y la efectividad de tales derechos y libertades".
Esta postura vuelve a recordar a los Estados la obligación de garantizar y velar por el respeto de los Derechos Humanos dentro de sus ordenamientos jurídicos, mencionando especialmente su carácter universal dentro de la categoría jurídica "derecho-deber"10, que puede derivarse de los artículos 29 y 30 de la citada Declaración ${ }^{11}$.

No es hasta la opinión consultiva sobre la legalidad del uso o amenaza de armas nucleares de 8 de julio de 1996, donde puede ser percibido un mayor fundamento interpretativo basado en los Derechos Humanos $^{12}$. A instancia de la Organiza-

10. Sobre la correlación entre derecho y deber, seguiré el planteamiento previsto, aunque exista cierta controversia, del profesor Lorenzo Peña en su artículo "La correlación lógico-jurídica entre deberes y derechos", publicado en Persona y Derecho: Revista de Fundamentación de las Instituciones Jurídicas y de Derechos Humanos del año 2009.

11. Si bien es cierto que la presente exposición no esté relacionada con lo previsto en la comunicación, considero que es necesario manifestar mi visión en cuanto a las normas procesales que los tribunales nacionales realizan con el fin de garantizar la seguridad jurídica y la existencia de los derechos humanos y fundamentales, pues, y atendiendo al caso objeto de resolución, sin el Derecho Procesal no podemos garantizar los mecanismos de protección esenciales para garantizar los Derechos Humanos que tienen todas las personas con independencia de su nacionalidad, ideología, raza, sexo, religión, profesión, etc.; derechos, junto con las libertades fundamentales, que se basan en los valores de convivencia de las personas dentro de una colectividad.

12. Para la ocasión, el Tribunal Internacional de Justicia estaba integrado por los jueces: Mohammed Bedjaoui, Presidente del Tribunal; Stephen M. Schwebel, Vicepresidente de dicho Tribunal; los jueces Shigeru Oda, Gilbert Guillaume, Mohammed Shahabuddeen, Christopher Weeramantry, Raymond Ranjeva, Géza Herczegh, Shi Jiuyong, Carl-August Fleischhauer, Abdul 
ción Mundial de la Salud, tras ser acogida su iniciativa por la Resolución de la Asamblea General de Naciones Unidas 49/75K de 15 de diciembre de 1994, se instó del Tribunal Internacional de Justicia, que emitiera dictamen sobre si el uso de armas nucleares es legal o no conforme a los principios y normas del Derecho Internacional y a la Carta de las Naciones Unidas.

La cuestión objeto de esta opinión consultiva fue formulada en los siguientes términos: "Is the threat or use of nuclear weapons in any circumstance permitted under international law?" (International Court of Justice, 1996: 16). Los miembros del Tribunal tuvieron que delimitar el significado de "permitido", tal y como había sido formulado atendiendo a la Resolución. La inclusión de dicho término ya fue criticada por algunos Estados, pues "this implied that the threat or the use of nuclear weapons would only be permissible if authorization could be found in a treaty provision or in customary international law" (International Court of Justice, 1996: 16), y el fondo de la cuestión planteada no es otra si "[s] tates are free to threaten or use nuclear weapons unless it can be shown that they are bound not to do so by reference to a prohibition in either treaty law or customary international law" (International Court of Justice, 1996: 16). En su consecuencia, los jueces de la Corte consideraron adecuado sustituir el término "permitido" por el de "prohibido", al ser

G. Koroma, Vladen S. Vereshchetin, Luigi Ferrari Bravo y Rosalyn Higgins. Igualmente, el juez de nacionalidad venezolana Andrés Aguilar Mawdsley formó parte de este Tribunal para esta opinión consultiva, pero falleció el 24 de octubre de 1995 en La Haya, hecho que fue mencionado por el magistrado Christopher Weeramantry en su voto particular. este más preciso para resolver conforme al Derecho Internacional aplicable ${ }^{13}$.

El Tribunal, para resolver esta cuestión, analiza desde una perspectiva científica el concepto de arma nuclear, y extiende su consideración al impacto y a las consecuencias que pueden acarrear su uso. Basándose en la definición existente en acuerdos interestatales determinan que: "nuclear weapons are explosive devices whose energy results from the fusion or fission of the atom. By its very nature, that process, in nuclear weapons as they exist today, releases not only immense quantities of heat and energy, but also powerful and prolonged radiation ${ }^{14}$. According to the material before the Court, the first two causes of damage are vastly more powerful than the damage caused by other weapons, while the phenomenon of radiation is said to be peculiar to nuclear weapons. These characteristics render the nuclear weapon potentially catastrophic. The destructive power of nuclear weapons cannot be contained in either space or time. They have the potential to destroy all civilization and the entire ecosystem of the planet" (International Court of Justice, 1996: 21).

13. Así: "Nor, however, is there any principle or rule of international law which would make the legality of the threat or use of nuclear weapons or of any other weapons dependent on a specific authorization. State practice shows that the illegality of the use of certain weapons as such does not result from an absence of authorization but, on the contrary, is formulated in terms of prohibition" (International Court of Justice, 1996: 25).

14. "The radiation released by a nuclear explosion would affect health, agriculture, natural resources and demography over a very wide área. Further, the use of nuclear weapons would be a serious danger to future generations. Ionizing radiation has the potential to damage the future environment, food and marine ecosystem, and to cause genetic defects and illness in future generations" (International Court of Justice, 1996: 21-22). 
La conceptuación de arma nuclear realizada por la Corte, se caracteriza por poner su énfasis en su capacidad destructiva y sus efectos perniciosos y permanentes de naturaleza catastrófica no sólo para el ser humano, sino para todo el planeta. Se trata, en su consecuencia, de un arma con potencialidad destructiva de toda la civilización y de todo el ecosistema del planeta, y así declara que "it is imperative (...) to take account of the unique characteristics of nuclear weapons, and in particular their destructive capacity, their capacity to cause untold human suffering, and their ability to cause damage to generations to come" (International Court of Justice, 1996: 22).

Concretada por la propia Corte los términos en el que debe de formar su opinión, así como el concepto de arma nuclear, de forma unánime declara que no existe norma convencional o consuetudinaria del Derecho Internacional que prohíba la amenaza o uso de armas nucleares, pero además por 11 votos contra $3^{15}$, de forma mayoritaria, también afirma que no existe en la norma convencional o consuetudinaria una prohibición universal sobre su uso, aunque existe una práctica por parte de los Estados de su utilización sólo con fines de disuasión, pero que ello no constituye en la situación actual la convicción obligatoria de la consideración ilícita de su uso, pues la discrepancia de la comunidad internacional sobre ello impide la existencia de opinio iuris a favor de su ilicitud.

Pero además, la opinión consultiva profundiza en la cuestión sobre su ilicitud basándose en el Derecho Humanitario, entendido el mismo como el núcleo esencial de protección de los Derechos Humanos en

15. Los jueces que votaron contra dicha decisión fueron los jueces Shahabuddeen, Weeramantry, y Koroma. caso de conflicto, distinguiendo además la situación que pudiera derivarse en una situación bélica, o en aquella situación de "paz". El Tribunal comienza por analizar los antecedentes internacionales tanto normativos como de precedentes judiciales aplicables al Derecho Humanitario, equiparándolas por su semejanza en cuanto a su capacidad de destrucción masiva y catastrófica con aquellas armas bacteriológicas o químicas. Así afirmó lo siguiente:

"(...) nuclear weapons should be treated in the same way as poisoned weapons. In that case, they would be prohibited under:

(a) the Second Hague Declaration of 29 July 1899, which prohibits "the use of projectiles the object of which is the diffusion of asphyxiating or deleterious gases";

(b) Article 23 (a) of the Regulations respecting the laws and customs of war on land annexed to the Hague Convention IV of 18 October 1907, whereby "it is especially forbidden: . . . to employ poison or poisoned weapons"; and

(c) the Geneva Protocol of 17 June 1925 which prohibits "the use in war of asphyxiating, poisonous or other gases, and of al1 analogous liquids, materials or devices" " (International Court of Justice, 1996: 26).

El propio Tribunal, aunque equipare las armas nucleares como "armas venenosas", se encuentran con la dificultad de que éstas carecen de definición uniforme dentro del Derecho Internacional. Así se deduce de "the Regulations annexed to the Hague Convention IV do not define what is to be understood by "poison or poisoned weapons" and that different interpretations exist on the issue. Nor does the 1925 Protocol specify the meaning to be given to the term "analogous materials or devices"” " International Court of 
Justice, 1996: 26) ${ }^{16}$, así como de la Convención de 10 de abril de 1972 sobre la Prohibición del desarrollo, producción y el almacenamiento de armas bacteriológicas, y de la Convención de 13 de enero de 1993 sobre la Prohibición del desarrollo, producción, almacenamiento y uso de armas químicas, pero observa que estos instrumentos fueron negociados y adoptados en un contexto determinado que no puede ser extendido a las armas nucleares (International Court of Justice, 1996: 26), y analizando específicamente las resoluciones adoptadas con relación a las armas nucleares, no encuentra que de las mismas se establezca una prohibición universal sobre su uso ${ }^{17}$.

A pesar de ello, y para el tiempo en conflicto bélico, la decisión del Tribunal es clara, y por unanimidad acuerdan que la amenaza y uso de armas nucleares debe cumplir con las exigencias del Derecho Internacional Humanitario, basándose en el principio de distinción entre objetivos militares y objetivos civiles, así como bajo el principio de prohibición de causar sufrimiento innecesario, y ello sólo puede ser permisivo en el supuesto del artículo 2.4

16. Así: "The terms have been understood, in the practice of States, in their ordinary sense as covering weapons whose prime, or even exclusive, effect is to poison or asphyxiate. This practice is clear, and the parties to those instruments have not treated them as referring to nuclear weapons" (International Court of Justice, 1996: 26).

17. El Tratado de Tlatelolco de 14 de febrero de 1967, sobre la prohibición del uso de armas nucleares en América Latina, el Tratado de Rarotonga de 6 de agosto de 1985, en virtud del cual establecen una zona libre de armas nucleares en el Sur del Pacífico por el que los Estados se comprometen a no fabricar, adquirir u poseer artefactos explosivos; el Tratado de no proliferación de armas nucleares de 1 de julio 1968, entre otros (International Court of Justice, 1996: 26-31). de la Carta de Naciones Unidas ${ }^{18}$ y dentro de los supuestos establecidos en el artículo 51 de la citada Carta ${ }^{19}$, y todo ello bajo condiciones de necesidad y proporcionalidad, como norma internacional consuetudinaria como declaró el propio Tribunal en el caso de las actividades militares y paramilitares en y contra Nicaragua de 27 de junio de 1986, cuando afirmó que "there is a specific rule whereby self-defence would warrant only measures which are proportionial to the armed attack and necessary to respond to it, a rule well established in customary international law" (International Court of Justice, 1986: 84).

En este sentido, la Corte fundamenta lo siguiente:

"The cardinal principles contained in the texts constituting the fabric of humanitarian

18. El artículo 2.4 de la Carta de las Naciones Unidas determina que: "Para la realización de los Propósitos consignados en el Artículo 1, la Organización y sus Miembros procederán de acuerdo con los siguientes Principios:

4. Los Miembros de la Organización, en sus relaciones internacionales, se abstendrán de recurrir a la amenaza o al uso de la fuerza contra la integridad territorial o la independencia política de cualquier Estado, o en cualquier otra forma incompatible con los Propósitos de las Naciones Unidas".

19. El citado precepto dispone lo siguiente: "Ninguna disposición de esta Carta menoscabará el derecho inmanente de legitima defensa, individual o colectiva, en caso de ataque armado contra un Miembro de las Naciones Unidas, hasta tanto que el Consejo de Seguridad haya tomado las medidas necesarias para mantener la paz y la seguridad internacionales. Las medidas tomadas por los Miembros en ejercicio del derecho de legítima defensa serán comunicadas inmediatamente al Consejo de Seguridad, y no afectarán en manera alguna la autoridad y responsabilidad del Consejo conforme a la presente Carta para ejercer en cualquier momento la acción que estime necesaria con el fin de mantener o restablecer la paz y la seguridad internacionales". 
law are the following. The first is aimed at the protection of the civilian population and civilian objects and establishes the distinction between combatants and non-combatants; States must never make civilians the object of attack and must consequently never use weapons that are incapable of distinguishing between civilian and military targets. According to the second principle, it is prohibited to cause unnecessary suffering to combatants: it is accordingly prohibited to use weapons causing them such harm or uselessly aggravating their suffering. In application of that second principle, States do not have unlimited freedom of choice of means in the weapons they use" (International Court of Justice, 1996: 35).

Igualmente, el Tribunal, tras remitirse a la Cláusula de Martens ${ }^{20}$, a la IV Convención de la Haya de 1907, y al caso del Canal de Corfú de 9 de abril de 1949, concluye, en relación con el Derecho Internacional Humanitario, lo siguiente:

"The extensive codification of humanitarian law and the extent of the accession to the resultant treaties, as well as the fact that the denunciation clauses that existed in the codification instruments have never been used, have provided the international community with a corpus of treaty rules the great majority of which had already become customary and which reflected the most univer-

20. Sobre la Cláusula de Martens y los citados principios, el Tribunal afirmó lo siguiente: "In conformity with the aforementioned principles, humanitarian law, at a very early stage, prohibited certain types of weapons either because of their indiscriminate effect on combatants and civilians or because of the unnecessary suffering caused to combatants, that is to Say, a harm greater than that unavoidable to achieve legitimate military objectives. If an envisaged use of weapons would not meet the requirements of humanitarian law, a threat to engage in such use would also be contrary to that law" (International Court of Justice, 1996: 35). sally recognized humanitarian principles. These rules indicate the normal conduct and behaviour expected of States" (International Court of Justice, 1996: 36).

En tiempos de paz, el derecho a no ser privado arbitrariamente de la vida, la protección a la salud y al bienestar de las personas, incluyendo en esta los Protocolos de defensa de los recursos naturales y del medio ambiente, fueron objeto de valoración por parte del Tribunal, si bien en su análisis concluye que "[i]t was said that those treaties made no mention of nuclear weapons. It was also pointed out that warfare in general, and nuclear warfare in particular, were not mentioned in their texts and that it would be destabilizing to the rule of law and to confidence in international negotiations if those treaties were now interpreted in such a way as to prohibit the use of nuclear weapons" (International Court of Justice, 1996: 19), pero a pesar de no hacerse de forma específica una consideración sobre la prohibición de armas nucleares, los magistrados contemplaron, en su fundamentación, el artículo II de la Convención de Ginebra sobre la Prevención y Sanción del delito de Genocidio de 9 de diciembre de $1948^{21}$.

21. Define el delito de genocidio como: "cualquiera de los actos mencionados a continuación, perpetrados con la intención de destruir, total o parcialmente, a un grupo nacional, étnico, racial o religioso, como tal:

a) Matanza de miembros del grupo;

b) Lesión grave a la integridad física o mental de los miembros del grupo;

c) Sometimiento intencional del grupo a condiciones de existencia que hayan de acarrear su destrucción física, total o parcial;

d) Medidas destinadas a impedir los nacimientos en el seno del grupo;

e) Traslado por fuerza de niños del grupo a otro grupo". 
Por ello, el uso de las armas nucleares difícilmente puede estar desprovisto de una intencionalidad que no constituya delito de genocidio, así "by the use of nuclear weapons would be enormous; that the victims could, in certain cases, include persons of a particular national, ethnic, racial or religious group; and that the intention to destroy such groups could be inferred from the fact that the user of the nuclear weapon would have omitted to take account of the well-known effects of the use of such weapons.

The Court would point out in that regard that the prohibition of genocide would be pertinent in this case if the recourse to nuclear weapons did indeed entail the element of intent, towards a group as such, required by the provision quoted above. In the view of the Court, it would only be possible to arrive at such a conclusion after having taken due account of the circumstances specific to each case" (International Court of Justice, 1996: 18).

Igualmente, la Corte reflexiona que por los efectos devastadores que conllevaría el uso de armas nucleares atentaría contra el medio ambiente (International Court of Justice, 1996: 20), declarando que "[t]he Court also recognizes that the environment is not an abstraction but represents the living space, the quality of life and the very health of human beings, including generations unborn" (International Court of Justice, 1996: 19) $)^{22}$. Por ello, conforme al artículo 2.4 de la Carta de Naciones Unidas,

22. Así, el Tribunal Internacional de Justicia cita, entre otros acuerdos y tratados, el Principio 24 de la Declaración de Rio de Janeiro de 1992, en virtud del cual determina que: "La guerra es, por definición, enemiga del desarrollo sostenible. En consecuencia, los Estados deberán respetar las disposiciones de derecho internacional que protegen al medio ambiente en épocas de conflicto de forma unánime establece la ilegalidad de la amenaza o empleo de la fuerza por medio de armas nucleares, pero al introducir los supuestos de legítima defensa del artículo 51, establece una excepción, cuya determinación corresponde a los Estados beligerantes, aunque se trate de supuestos muy excepcionales de supervivencia de los Estados en conflicto.

Las armas nucleares, como cualquier tipo de arma, incluida las convencionales, tienen capacidad para ser utilizadas en tiempos de conflictos armados, pero en este caso el Derecho Internacional aplicable debe extraerse de las normas de Derecho Humanitario y del principio de neutralidad, lo que implica como hemos expuesto que este recurso esté específicamente prohibido.

La decisión conclusiva del Tribunal fue objeto de controversia, y donde se manifiesta la discrepancia de sus miembros ${ }^{23}$. La decisión adoptada por el voto cualitativo del Presidente, quedó establecida en los términos siguientes: "It follows from the above-mentioned requirements that the threat or use of nuclear weapons would generally be contrary to the rules of international law applicable in armed conflict, and in particular the principles and rules of humanitarian law; However, in view of the current state of international law, and of the elements of fact at its disposal, the Court cannot conclude definitively whether the threat or use of nuclear weapons would be lawful or unlawful in an extreme circumstance of self-defence, in which the

armado, y cooperar en su ulterior desarrollo, según sea necesario".

23. Los votos discrepantes de la citada decisión conclusiva fueron los magistrados Schwebel, Oda, Guillaume, Shahabuddeen, Weeramantry, Koroma y Higgins. 
very survival of a State would be at stake" (International Court of Justice, 1996: 44).

Precisamente, aunque la opinión emanada del Tribunal señala que la amenaza o el empleo de armas nucleares sería en general contrario a las normas del Derecho Internacional, desconcierta la falta de claridad introducida cuando señala que no puede concluir su legalidad en circunstancias extremas de legítima defensa en que estuviese en juego "la supervivencia misma de un Estado", y esta posición confusa y no clara, que incurre en la prohibición del principio non liquet, que no sería admisible en la solución contenciosa, pero posiblemente permisible en las opiniones consultivas conforme al artículo 68 del Estatuto del Tribunal, resulta de extraordinaria importancia a la hora de reinterpretar el denominado "principio Lotus", que de forma tradicional ha servido como cláusula de cierre en el Derecho Internacional Clásico (lo que no está prohibido por norma convencional o consuetudinaria, o principio de Derecho Internacional, es permisible para los Estados), y por eso concluye como deseo de futuro para la comunidad internacional, y por unanimidad que "exists an obligation to pursue in good faith and bring to a conclusion negotiations leading to nuclear disarmament in all its aspects under strict and effective international control" (International Court of Justice, 1996: 45), en la convicción de que el desarme nuclear llegará a imponerse de forma mayoritaria en la comunidad internacional.

Por ello resulta conveniente analizar las opiniones de los magistrados integrantes del Tribunal, tanto aquellos que expresaron su discrepancia con la opinión mayoritaria como aquellos que, aun compartiéndola, procedieron a una fundamentación separada de la misma.
Comenzando por las declaraciones del Presidente Mohammed Bedjaoui y el juez Luigi Ferrari Bravo merecen especial atención, pues consideran que hicieron todo lo necesario para alcanzar tal decisión atendiendo a las normas convencionales y consuetudinarias del Derecho Internacional. El juez Ferrari Bravo considera, en relación con el fenómeno de las armas nucleares y la evolución de las normas convencionales y consuetudinarias del Derecho Internacional, afirma que “[c]e phénomène n'est pas nouveau, car à toute époque de son développement, dès le début de l'ère moderne, le droit international qui est essentiellement un droit coutumier, donc de formation spontanée, a connu des situations où la force de certaines règles empêchait les règles contraires de s'établir ou de se maintenir" (International Court of Justice, 1996: 63).

Para el Presidente Mohammed Bedjaoui, a pesar de admitir que la aplicación del principio Lotus debía aplicarse en un supuesto muy concreto y en un contexto muy específico, considera que "[l]a décision en question exprimait sans aucun doute l'air du temps, celui d'une société internationale encore très peu institutionnalisée et régie par un droit international de stricte coexistence, lui-même reflet de la vigueur du principe de la souveraineté de l'Etat" (International Court of Justice, 1996: 48) ${ }^{24}$. Igualmente, y recordando el

24. En el asunto Lotus de 7 de septiembre de 1927, la Corte Permanente de Justicia Internacional afirmó, en relación con la obligación del Derecho Internacional de respetar el principio de la soberanía de los Estados, lo siguiente: "international law governs relations between independent States. The rules of law binding upon States therefore emanate from their own free will as expressed in conventions or by usages generally accepted as expressing principles of law and established in order to regulate the relations be- 
lanzamiento de las bombas atómicas en las ciudades de Hiroshima y Nagasaki, resalta lo siguiente: "Avec l'arme nucléaire, l'humanité est comme en sursis. Ce terrifiant moyen de destruction massive fait partie, depuis un demi-siècle, de la condition humaine. L'arme nucléaire est entrée dans tous les calculs, dans tous les scénarios, dans tous les schémas" (International Court of Justice, 1996: 46).

Por último, el juez Bedjaoui concluye su declaración así: "La solution dégagée par le présent avis consultatif fait le constat sans complaisance de la réalité juridique, tout en exprimant et traduisant fidèlement l'espoir, partagé par tous, peuples et Etats, que le but ultime de toute action dans le domaine des armes nucléaires restera toujours le désarmement nucléaire, que ce but n'est plus utopique et qu'il est du devoir de tous de le rechercher plus activement que jamais. De l'existence de cette volonté d'engagement dépend le destin de l'homme car, comme l'écrivait Albert Einstein, «le sort de l'humanité sera celui qu'elle méritera»" (International Court of Justice, 1996: 52).

Los jueces Gilbert Guillaume, Raymond Ranjeva, y Carl-August Fleischhauer realizaron sus votos separados, al mostrarse discrepantes en algunos aspectos de

tween these co-existing independent communities or with a view to the achievement of common aims. Restrictions upon the independence of States cannot therefore be presumed" (Permanent Court of International Justice, 1927: 18).

Igualmente, en el caso de las actividades paramilitares contra Nicaragua de 27 de junio de 1986, el Tribunal Internacional de Justicia afirmó lo siguiente: "in international law there are no rules, other than such rules as may be accepted by the State concerned, by treaty or otherwise, whereby the level of armaments of a sovereign State can be limited, and this principle is valid for all States without exception" (International Court of Justice, 1986: 135). la opinión consultiva. Los magistrados Stephen M. Schwebel, Abdul G. Koroma, Shigeru Oda, Mohammed Shahabuddeen, Christopher Weeramantry, y Rosalyn Higgins se mostraron discrepantes con el sentir mayoritario de la opinión consultiva. En sus votos, todos ellos comparten la importancia de las circunstancias históricas tras la Segunda Guerra Mundial, especialmente con el lanzamiento de las bombas atómicas en las ciudades japonesas de Hiroshima y Nagasaki en 1945. Se centraron en la importancia del Derecho Internacional Humanitario en este caso, así como la importancia de los términos "amenaza", "uso" y "prohibición" en las normas escritas acerca de las armas nucleares (por cuanto la experiencia de los Estados ha demostrado el incumplimiento del principio de neutralidad y de proporcionalidad en cuanto al impacto que produce su uso, incluso en los casos de legítima defensa), no debemos olvidar que sus fundamentos de derecho se centran en las obligaciones que tienen los Estados no sólo con el Derecho Internacional, sino también con sus nacionales y no nacionales en velar por la seguridad jurídica y asegurar que su ordenamiento jurídico garantice su ejercicio soberano conforme a su Derecho Interno e Internacional.

Si concebimos el Derecho Internacional como un sistema normativo, cuya centralidad viene determinada por la Carta de Naciones Unidas y la Declaración Universal de los Derechos Humanos, el principio general de toda civilización no es otro que la protección de la dignidad humana, y este principio debe ser intrínseco a toda norma convencional o consuetudinaria, y por ello recurso ineludible de aplicación en la resolución de todo conflicto internacional, así como de cuantas consultas sean solicitadas a la Corte Internacional de Justicia. 


\section{Conclusiones}

La Declaración Universal de los Derechos Humanos, supuso la internacionalización de los derechos fundamentales reconocidos por las constituciones occidentales. Aprobada por la Resolución 217(III) de la Asamblea General de Naciones Unidas, carece de efecto jurídico vinculante para los Estados miembros, pues la Conferencia de San Francisco de 10 de diciembre de 1948 rechazó que tuviera competencia alguna para promulgar normas obligatorias.

Ello no impide la aparición de un nuevo consenso internacional como valor generalmente aceptado por la comunidad de Naciones al suponer la concreción de los valores de dignidad humana y democracia, como eje central de la civilización donde el ser humano es titular de derechos propios y oponibles frente a los Estados.

En la Declaración Universal, se concretan principios jurídicos que legitiman la aplicación de toda norma tanto en el Derecho Interno como Internacional. Considero, siguiendo al jurista Antônio Augusto Cançado Trindade, que debe entenderse por "principio" aquella concreción de valores que protege el orden jurídico dentro de una colectividad, garantizando su legalidad y legitimidad tanto a las normas jurídicas como al sistema jurídico (Corte Interamericana De Derechos Humanos, 2003: 17-19)25.

La Declaración Universal de los Derechos Humanos, junto con sus nueve tratados y protocolos que la complementan, son la garantía para la eficacia jurídica de

25. Definición recogida en la Opinión Consultiva de la Corte Interamericana de Derechos Humanos sobre la Condición jurídica y derechos de los migrantes indocumentados de 17 de septiembre de 2003, concretamente en su voto concurrente. los mismos, superando su mero carácter simbólico y supone una dimensión diferente del Derecho Internacional contemporáneo, y ello viene reforzado de forma progresiva por la jurisprudencia del Tribunal Internacional de Justicia, en base a lo establecido en el artículo 38.1 c) de su Estatuto ${ }^{26}$, la aplicación de los principios generales de Derecho Internacional, que en una interpretación flexible ha ido introduciendo en sus resoluciones, aunque debemos admitir que sólo excepcionalmente ha basado sus decisiones en la propia Declaración Universal ${ }^{27}$.

Es en la Opinión Consultiva sobre el uso o amenaza de las armas nucleares donde se aprecia una cierta centralidad de la Declaración Universal de los Derechos Humanos, al concretar los valores univer-

26. El citado precepto determina que la "Corte, cuya función es decidir conforme al derecho internacional las controversias sometidas, deberá aplicar: (...) c) los principios generales de derecho reconocidos por las naciones civilizadas".

27. No obstante, y de acuerdo con la profesora Sáenz de Santamaría, debemos diferenciar los principios de las naciones civilizadas de los llamados principios puros del Derecho Internacional, que están previstos en la resolución de la Asamblea General de las Naciones Unidas A/RES/2625 (XXV), de los que podemos citar: la abstención de recurrir a la amenaza o el uso de la fuerza contra la integridad territorial o la independencia política de cualquier Estado, la resolución de las controversias internacionales por medios pacíficos para no poner en peligro la paz, seguridad internacional y la justicia; la no intervención en los asuntos internos de un Estado, la obligación de los Estados de cooperar entre sí conforme a lo establecido en la Carta de Naciones Unidas, el principio de igualdad de derechos y de la libre determinación de los pueblos, el principio de igualdad soberana entre los Estados, y el principio de cumplir de buena fe las obligaciones de conformidad con la Carta (Sáenz de Santamaría, 2012: 25-26). 
sales de la humanidad y de la civilización en los principios de protección a la vida, a la salud y al ecosistema, analizado desde la experiencia histórica y situación actual, que en mi opinión supuso un cambio de los principios que eran de aplicación en el Derecho Internacional Clásico, basado en la supremacía de los principios de no intervención e igualdad soberana de los Estados, y ello determinó que en su jurisprudencia "cerrara" su sistema normativo en la aplicación de las normas internacionales con la Declaración de que todo aquello que no estuviere prohibido por normas convencionales o consuetudinarias de Derecho Internacional, debe considerarse permitido, como manifestación de la libertad soberana de los Estados, lo que es conocido como el principio Lotus, que en su formulación realizada por la sentencia de 7 de septiembre de 1927 de la Corte Permanente de Justicia Internacional, supone desde el punto de vista de los Estados como sujetos de Derecho Internacional, un instrumento que evita infringir el principio de "prohibición de non liquet", necesario para el ejercicio de la competencia universal por parte de los tribunales internacionales.

La decisión de la Opinión Consultiva, a pesar de que determinó por unanimidad la no existencia de norma internacional alguna que prohíba la amenaza o uso de armas nucleares, consideró, a la vista de las circunstancias históricas y de la definición de arma nuclear, que su uso por parte de los Estados es contrario al Derecho Internacional. Y como arma, sería contrario al Derecho Internacional Humanitario por sus efectos devastadores, con la única excepción, por otra parte, hipotética, de estar en peligro la propia supervivencia del Estado.

La Opinión Consultiva sobre el uso de armas nucleares, comparte con la sentencia del asunto Lotus la necesidad de resolver si los hechos objeto de pronunciamiento judicial son conformes al Derecho Internacional, y ante esta cuestión oscura en cuanto a las normas de aplicación, para evitar infringir el principio de prohibición non liquet, el Tribunal da su opinión matizando el principio jurídico establecido como precedente en la sentencia que resolvió el asunto Lotus, al establecer la centralidad de los principios emanados de la Declaración Universal de los Derechos Humanos.

Esta idea, sin embargo, entiendo que ya estuvo presente en el propio debate y resolución del asunto Lotus, pues de la mano del Derecho Humanitario, debemos recordar la posición mantenida por Rafael Altamira, quien en su voto particular, pone de manifiesto la centralidad del hombre como sujeto de Derecho, fundamentando su posición al considerar que la libertad de los Estados no es permisible cuando en su actuación vulnera, no sólo las normas convencionales o consuetudinarias, sino también los principios de humanidad, que desde su perspectiva iusnaturalista son compartidos por la comunidad internacional en su conjunto.

Esta centralidad de los Derechos Humanos constituye su relevancia en el sistema normativo del Derecho Internacional, y como principio debe ser tenido en cuenta por parte del Tribunal Internacional de Justicia.

\section{Bibliografía}

Bedi, Shiv R.S. (2007). "The development of Human Rights Law by the judges of the International Court of Justice". Studies in International Law, Volume 10, Oxford: Hart Publishing. 
Carta de las Naciones Unidas de 26 de junio de 1945.

Convención de Ginebra sobre la Prevención y Sanción del delito de Genocidio de 9 de diciembre de 1948.

Corte Interamericana de Derechos Humanos. (2003). "Opinión Consultiva sobre la Condición Jurídica y derechos de los migrantes indocumentados, Voto Concurrente del Juez A.A. Cançado Trindade". Opinión Consultiva, $\mathrm{n}^{\circ}$ de referencia OC18/03, Serie A, no 18, de 17 de septiembre de 2003. Disponible en: http://www. corteidh.or.cr/cf/Jurisprudencia2/busqueda_opiniones_consultivas.cfm?lang=es [1 de junio de 2019].

Declaración de Río de Janeiro de 1992, del 3 al 14 de junio.

Declaración Universal de los Derechos Humanos de 10 de diciembre de 1948.

Estatuto del Tribunal Internacional de Justicia de 26 de junio de 1945.

Handeyside, Hugh. (2007). "The Lotus Principle in ICJ Jurisprudence: Was the Ship ever Afloat?", Michigan Journal of International Law, Volume 29, Issue 1.

Hertogen, An. (2016). "Letting Lotus Bloom", The European Journal of International Law, Volume 26, Issue 4. Italy: European University Institute.

Higgins, Rosalyn. (1994). Problems and Process: International Law and How we use it. Oxford: Clarendon Press Publication.

Higgins, Rosalyn. (1998). "The International Court of Justice and Human Rights", en Wellens, Karen C. [ed.], International Law: Theory and Practice. Essays in Honour of Eric Suy. The Hague: Martinus Nijhoff Publishers.

International Court of Justice. (1950a). "Interpretation of Peace Treaties with Bulgaria, Hungary and Romania. First Phase". Advisory Opinion, General List $n^{\circ} 8$, of 30 March 1950.
International Court of Justice. (1950b). "Interpretation of Peace Treaties with Bulgaria, Hungary and Romania. Second Phase". Advisory Opinion, General List $n^{\circ}$ 8, of 18 July 1950.

International Court of Justice. (1966). "South West Africa Cases (Ethiopia v. South Africa; Liberia v. South Africa). Second Phase". Judgment, General List $n^{0}$ 46 \& 47, of 18 July 1966. Disponible en: https://www.icj-cij.org/en/case/47/judgments [12 de mayo 2019].

International Court of Justice. (1971). "Legal Consequences for States of the Continued Presence of South Africa in Namibia (South West Africa) notwithstanding Security Council Resolution 276 (1970)". Advisory Opinion, General List $n^{\circ}$ 53, of 21 June 1971. Disponible en: https://www.icj-cij.org/en/case/53 [9 de mayo de 2019].

International Court of Justice. (1986). "Case concerning military and paramilitary activities in and against Nicaragua, Nicaragua v. United States of America, Merits". Judgment, General List $n^{\circ} 70$, of 27 June 1986. Disponible en: https:// www.icj-cij.org/en/case/70/judgments [7 de mayo 2019].

International Court of Justice. (1996). "Legality of the threat or use of nuclear weapons". Advisory Opinion, General List $n^{\circ}$ 95, of 8 July 1996. Disponible en: https:// www.icj-cij.org/en/case/95 [5 de mayo de 2019].

International Court of Justice. (2011). "Case Concerning Application of the International Convention on The Elimination of All Forms of Racial Discrimination (Georgia v. Russian Federation), Preliminary Objections". Judgment, General List $n^{\circ}$ 140, of 1 April 2011.

International Court of Justice. (2017). "Application of the International Convention for the Suppression of The Financing 
of Terrorism and of The International Convention on the Elimination of All Forms of Racial Discrimination (Ukraine v. Russian Federation). Request for the indication of Provisional Measures". Order, General List no 166, of 19 April 2017.

International Court of Justice. (2018). "Application of the International Convention on the Elimination of All Forms of Racial Discrimination (Qatar V. United Arab Emirates). Request for the indication of Provisional Measures". Order, General List $n^{\circ} 172$, of 23 July 2018.

International Court of Justice. (2019). "Application of the International Convention on the Elimination of All Forms of Racial Discrimination (Qatar V. United Arab Emirates). Request for the indication of Provisional Measures". Order, General List n 172, of 14 June 2019.

Macklem, Patrick. (2015). The Sovereignty of Human Rights. New York: Oxford University Press.

Nino, Carlos Santiago. (1989). Ética y Derechos Humanos. Un ensayo de fundamentación". Ariel Derecho. Barcelona: Ariel.

O'Neill, Teresa. (2017). Rethinking the Lotus Principle: New perspectives on the Kosovo Advisory Opinion, Supervisor: Jeutner, Valentin. Master Thesis, Spring, International Human Rights Law, Faculty of Law, Sweden: Lund University.

Pérez Luño, Antonio-Enrique. (2007). Los Derechos Fundamentales. Temas Clave de la Constitución Española. Madrid: Tecnos, $8^{a}$ Edición.

Permanent Court of International Justice. (1927). "The Case of the S.S. Lotus, France v. Turkey", Judgment, 7 September 1927. Publications of the Permanent Court of International Justice, No. 10, Series A. Disponible en: https://www.icj-cij. org/en/pcij-series-a [5 de mayo de 2019].
Rieter, Eva. (2019). “The International Court of Justice and its contribution to Human Rights Law", en Kadelbach, Stefan; Rensmann, Thilo y Rieter, Eva [eds.], Judging International Human Rights. Courts of General Jurisdiction as Human Courts. Switzerland: Springer International Publishing A.G.

Sáenz de Santamaría, Paz Andrés. (2012). Sistema de Derecho Internacional Público. Navarra: Thomson Reuders, Civitas, $2^{a}$ Edición.

Švarc Pipan, Dominika. (2018). "The contribution of the International Court of Justice to the promotion and protection of Human Rights". En Follesdal, Andreas; y Ulfstein, Geir [eds]. The Judicialization of International Law: A mixed blessing? The United Kingdom: Oxford University Press. Zyberi, Gentian. (2008). The Humanitarian Face of the International Court of Justice. Its Contribution to Interpreting and Developing International Human Rights and Humanitarian Law Rules and Principles. Supervisor: Flinterman, Cees; and Gill, Terry, The Netherlands: Utretch University. Disponible en: https://dspace. library.uu.nl/handle/1874/26885 [18 de abril de 2019]. 